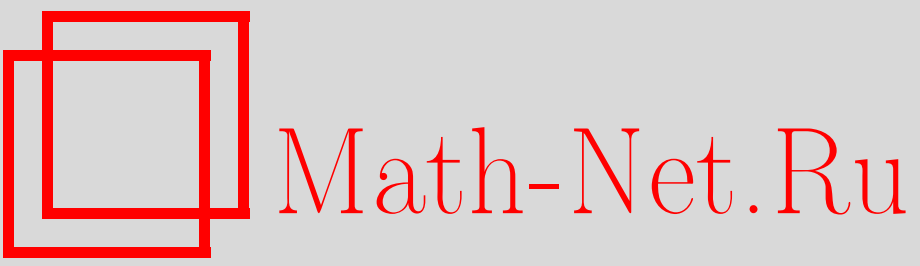

П. З. Агранович, А. А. Гольдберг, В. П. Гурарий, В. А. Марченко, С. П. Новиков, И. В. Островский, Л. А. Пастур, А. Ю. Рашковский, С. Ю. Фаворов, Е. Я. Хруслов, Лев Исаакович Ронкин (некролог), УМН, 1999, том 54, выпуск 3, 147-148

DOI: https://doi.org/10.4213/rm154

Использование Общероссийского математического портала Math-Net.Ru подразумевает, что вы прочитали и согласны с пользовательским соглашением

http: //www. mathnet.ru/rus/agreement

Параметры загрузки:

IP : 52.6 .47 .48

26 апреля 2023 г., 09:59:47 


\section{ЛЕВ ИСААКОВИЧ РОНКИН}

8 апреля 1998 года скоропостижно скончался доктор физико-математических наук профессор Лев Исаакович Ронкин. От нас ушел выдающийся ученый и замечательный человек.

Лев Исаакович Ронкин родился 2 января 1931 года в Харькове. Еше в старших классах средней школы у него проявился интерес к математике. С группой своих соучеников, среди которых были ставшие впоследствии известными математиками и физиками Ю. Любич, М. Азбель, В. Малеев, он организовал математический кружок, на котором они самостоятельно изучали вопросы, выходившие за рамки школьной программы.

В 1948 году Лев Исаакович поступил на физико-математический факультет Харьковского университета. Спектр его увлечений в те годы был очень широк: математика, акробатика, альпинизм. На третьем курсе он начал посешать спецкурс Б.Я. Левина "Почти периодические функции", и Борис Яковлевич предложил ему задачу, связанную с почти периодическими функциями Левитана. С рассмотрения этого вопроса началась научная деятельность Л.И. Ронкина, и уже в 1953 году им была опубликована статья "Об аппроксимации целых функций тригонометрическими полиномами" (ДАН СССР, 1953); ее результаты, относящиеся к целым функциям одной и нескольких переменных, не превзойдены до настоящего времени и используются специалистами.

По окончании университета Лев Исаакович получил назначение в Минск преподавателем вечерней школы. Работая там, он продолжал активно заниматься математикой, поддерживая постоянный контакт с Б.Я. Левиным, который заинтересовал его рядом вопросов, относящихся к целым функциям многих комплексных переменных.

В 1958 году, возвратившись в Харьков, Л.И. Ронкин начал преподавать математику в Харьковском авиационном институте и в том же году защитил кандидатскую диссертацию на тему "Целые функции конечной степени многих переменных". Продолжая работу в этом направлении, Лев Исаакович получил ряд фундаментальных результатов о росте и нулевых множествах целых функций многих переменных и, по сути, стал одним из создателей многомерной теории целых функций. Им введены такие характеристики роста, как гиперповерхности сопряженных порядков и типов, и показано, что они применимы к изучению функций более широкого класса, чем целые. Для изучения роста и распределения нулей по каждой из переменных при фиксированных остальных Л.И. Ронкин разработал общий подход, состоящий в использовании методов теории плюрисубгармонических функций и теории потенциала. Это позволило ему получить точные и законченные результаты о множествах понижения порядка функции и показателя сходимости корней в случае $n=2(n-$ размерность пространства). При $n>2$ отсутствие подходящих характеристик "редкости" множеств привело его к построению $Г$-емкости - новой емкостной характеристики, которая впервые позволила получить результаты о множествах понижения и при $n>2$. 
В 1967 году Лев Исаакович защитил докторскую диссертацию, резултаты которой позднее легли в основу его монографиии "Введение в теорию целых функций многих переменных" (Наука, 1971). Она была переведена в 1974 году в США и с тех пор широко используется математиками всего мира, работающими в области многомерной теории функций.

Почти тридцать лет, с 1969 года, Л.И. Ронкин проработал в отделе теории функций Физико-технического института низких температур НАН Украины. В эти годы Лев Исаакович получил основополагающие результаты в целом ряде вопросов многомерного комплексного анализа. Им были исследованы дискретные множества единственности для целых функций многих переменных и полнота систем экспонент, установлены важные факты о сепаратно-аналитических функциях, доказаны глубокие теоремы об интерполяции целых функций с алгебраических и псевдоалгебраических множеств, о сходимости потоков Монжа-Ампера и по многомерной неванлинновской теории.

В середине 70-х Л.И. Ронкин приступил к исследованиям функций вполне регулярного роста многих переменных. Одним из первых он понял важность эффекта слабой сходимости в пространствах обобщенных функций для исследования асимптотического поведения и распределения нулей аналитических функций. Метод слабой сходимости оказался плодотворным для изучения различных классов функций: целых и голоморфных одной и нескольких комплексных переменных, плюрисубгармонических и субгармонических во всем пространстве и в конусе. Результаты, полученные Л. И. Ронкиным, его учениками и коллегами из разных стран, составили содержание его книги "Функции вполне регулярного роста", изданной в 1992 году в Голландии.

Последние десять лет своей жизни Лев Исаакович посвятил изучению почти-периодичности. Как итог этой деятельности им была задумана и начата книга под условным названием "Почти периодические объекты комплексного анализа", работу над которой он продолжал и в свой последний день. Метод слабой сходимости оказался чрезвычайно эффективным при исследовании этих вопросов. Он позволил Л. И. Ронкину ввести и исследовать такие общие понятия как почти периодические потоки, дивизоры и голоморфные цепи, а также изучить распределение нулевых множеств голоморфных почти периодических отображений и выделить классы почти периодических дивизоров, реализуемых как дивизоры почти периодических функций.

Активную научную работу Лев Исаакович сочетал с преподаванием на кафедре теории функций Харьковского университета. Его замечательные лекции были опубликованы в виде учебника ( “Элементы теории аналитических функций многих переменных", Киев, 1977). Талант педагога позволил ему сделать - впервые в мировой литературе - такой материал интересным как математикам, так и инженерам. Многие годы он руководил созданным им семинаром по многомерному комплексному анализу и воспитал целых группу активно работающих математиков.

Л. И. Ронкин - автор более 80 научных статей. Оригинальные идеи и методы этих работ широко используются математиками разных стран.

Большой знаток и любитель истории и литературы, интереснейший собеседник, Лев Исаакович всегда привлекал к себе людей, заряжая их своим оптимизмом и энергией. Среди его многочисленных хобби особое место занимало фотографиирование; он владел этим искусством почти на профессиональном уровне. Им создана уникальная коллекция фотоснимков математиков второй половины двадцатого века.

Все, кому посчастливилось обшаться со Львом Исааковичем Ронкиныт, надолго сохранят о нем благодарную память.

П. З. Агранович, А. А. Гольдберг, В. П. Гурарий, В. А. Марченко, С. П. Новиков, И. В. Островский, Л. А. Пастур, А. Ю. Рашковский, С. Ю. Фаворов, Е. Я. Хруслов 